UDC 911.3

DOI 10.32999/ksu2413-7391/2019-10-18

\author{
Denysyk H.I., \\ Doctor of Geography Sciences, Professor, \\ Head of the Department of Geography \\ Vinnytsia Mykhailo Kotsiubynskyi State Pedagogical University
}

Didura R.V.,

Postgraduate Student at the Department of Geography

Vinnytsia Mykhailo Kotsiubynskyi State Pedagogical University

\title{
ACCUMULATION OF HEAVY METALS IN ROAD LANDSCAPE ENGINEERING SYSTEMS
}

The heavy metals content in the soil was investigated within the road landscape engineering system of Kyiv - Odesa. The heavy metals as $\mathrm{Cu}, \mathrm{Zn}, \mathrm{Pb}$ and $\mathrm{Cd}$ of the first and second classes of danger were detected. Four full-size areas for research were selected: the first one is near the town of Bila Tserkva (Kyiv region), the second one is located near the village of Nesterivka (Cherkasy region), the third part of the study is near the village of Pikivets (Cherkasy region), the fourth - near the city of Uman on the fork "clover leaf" (Cherkasy region). It is established that the content of the mobile form of $\mathrm{Cu}, \mathrm{Zn}, \mathrm{Pb}$ and $\mathrm{Cd}$ in the soil varies in different ways. Zinc dissipates and decreases by MPC from the source of pollution and at a distance of $15 \mathrm{~m}$ from the road reaches its minimum. Like zinc the cadmium is scattered at a distance of $15 \mathrm{~m}$ from the canvas road, the MPC falls to a minimum value. Plumbum in local background areas shows different tendencies for dispersion. Copper on all studied areas is within the limits of the norm and shows a decrease in the amount of concentration from the roadway. However, small areas with an abnormal content of zinc of $40,9 \mathrm{mg} / \mathrm{kg}$ have been recorded; Excess of zinc content in this area is observed since 2016. The research results provide up-to-date reliable information that can be used by monitoring services in the process of development of anti-degradation and optimization measures for the operation of not only the Kyiv - Odesa highway, but also other road engineering and landscape systems in Ukraine. In the future, these studies may enter the information base for further development of future projects and plans for the development and operation of road landscape engineering systems, rational use and protection of the surrounding landscapes.

Key words: road landscape engineering system, Kyiv - Odesa highway, heavy metals, area, maximum permissible concentrate (MPC), soil pollution, migration, accumulation.

\section{Денисик Г.ї., Дідура Р.В. АКУМУЛЯція вАЖКИХ МЕТАЛї у дОРОЖніХ ЛАНДШАФТНО-ІНЖЕНЕРНИХ СИСТЕМАХ}

Розглянуто проблему забруднення грунту важкими металами прилеглих територій до автомагістралі Київ - Одеса; проаналізовано попередні праці зарубіжних та вітчизняних науковців. Охарактеризовано природні умови дослідження, виділено ділянки для взяття проб грунту: перша знаходиться біля м. Біла Церква (Київська обл.), друга розташована в околицях с. Нестерівка (Черкаська обл.), третя - поблизу с. Піківець (Черкаська обл.), четверта - біля м. Умань на розвилці «Лист конюшини» доріг Київ - Одеса і М - 12 Стрий - Тернопіль - Кропивницький - Знам'янка. Результати дослідження придорожніх територій дорожньої ландшафтно-інженерної системи Київ - Одеса показали, що у грунті наявні такі хімічні елементи: цинк, мідь, свинець та кадмій. Зразки грунту відбирали на відстані 5, 10 та 15 м від полотна автодороги, на глибині 0-10 см у ясну погоду. Майже всі хімічні елементи знаходяться в межах норми ГДК, однак зустрічаються й аномальні ділянки. Цинк знаходиться в межах норми на всіх ділянках дослідження, лише локальна фонова ділянка поблизу м. Умань на розвилці «Лист конюшини» містить аномальну для довкілля зону, де вміст Zn на відстані 10 м від полотна дороги становить 40,90 мг/кг, що перевищує значення рухомої форми ГДК у два рази. Плюмбум перевищує ГДК майже на всіх натурних ділянках, крім с. Нестерівка (Черкаська обл.), це пояснюється значною кількістю автомобілів на трасі Київ - Одеса та меншою їх кількістю у з'їзд до с. Нестерівка. Вміст кадмію на натурних ділянках малопомітний, знаходиться в нормі і не становить загрози для навколишнього середовища. Вміст міді на всіх локальних ділянках коливається в межах норми. Встановлено, що вміст хімічних елементів у грунті на досліджуваних ділянках за період 2016-2018 років зменшився.

Ключові слова: дорожня ландшафтно-інженерна система, автодорога Київ - Одеса, важкі метали, ділянка, ГДК, забруднення грунтів, міграція, акумуляція. 
Problem statement. Compared with the middle of the twentieth century the number of cars in Ukraine has increased by almost 4 times, which leads to the active development of road landscapes. 9.2 million vehicles are registered in Ukraine in 2017. Roads, overpasses, bridges, interchanges which form new road landscape engineering systems are being built for their functioning. Such an active human activity leads to the formation of environmental problems; one of the problems is the pollution of soils with heavy metals. Excessive amount of heavy metals in roadside soils forwards to changes of physical and chemical qualities, especially the humus layer $(0-50 \mathrm{~cm})$. Some chemical elements in their excessive concentrations cause various human diseases. They can cause carcinogenic effects and mutations in the structure of human and animal DNA. This causes to the necessity of constant control of heavy metals content, especially in areas where agricultural land is close to highways.

Analysis of recent research and publications. A number of interesting publications of foreign and national scientists is devoted to the problem of soil pollution by heavy metals within the boundaries and territories close to the road landscape engineering systems (Шейкіна, 2008; Юрченко, 2014; Li, 2001; Saeedi, 2009).

E.K. Eskov, M.D. Eskova and L. V. Sira have investigated the content of heavy metals, especially of plumbum, in plants at highway zones (Еськов, 2012). V. Bryhadyrenko and O.S. Chernysh have analyzed the geochemical impact of highway on roadside plantations of Dnipropetrovsk region. R.B. Vanchura has made a comparative description of the content of heavy metals on the highway areas on the territories of Ukraine and Germany (Ванчура, 2011). O.V. Grabovsky has studied migration and accumulation of heavy metals in agrocenoses close to highways in the Transcarpathian region (Грабовський, 2002). In Polissya, the content of heavy metals in the soil was investigated by L.L. Dovbysh (Довбиш, 2001). G.I. Denysyk and A.M. Valchuk-Orkhusha have highlighted the stages of formation of the road landscapes of Podillya area, investigated their structure, regional types, geochemical and ecological features, made their classification and zoning (Денисик, 2005). On the territory of Chernivtsi region, the eco-geochemical evaluation of road geosystems was made by M.V. Tanasiuk and G.D. Khodan (Ходан, 2012). Y.I. Chykailo has investigated the road landscape engineering system of the Lviv - Krakovets highway. The scientist has conducted the ecological and geochemical analysis of the soil and vegetation cover within the range (representative areas) along the road lanes of the $\mathrm{M}-10$ highway; the ecological state of water objects within the boundaries of the road landscape-engineering system was analyzed; optimization measures were offered to improve the ecological state of areas close to highways. I.M. Voloshyn and O.O. Halahan have investigated road landscape systems and peculiarities of pollution of territory along the highway in Volyn and modeled the distribution of heavy metals in the geosystems close to highways (Галаган, 2013; Волошин,2005; Матвійчук, 2008).

Identification of previously unsettled parts of the general problem. National and foreign scientists are sporadically engaged in the research on the content of heavy metals in the soils of road landscape and engineering systems, seeking ways to reduce and optimize heavy metals in these systems. However, in Ukraine at the beginning of the XXI century there are no unique sanitary-normative documents for the regulation of ecological safety of the road landscape engineering systems, based on their detailed geochemical research. For the most part, scientists investigate the content of the heavy metals near different landscape engineering systems: companies of iron-and-steel industry, aerodromes, gas stations and others (Яковенко, 2011). The semi-station geochemical research was conducted for the first time within the Kyiv - Odesa road-landscape engineering system.

Aim of the article: soil monitoring on the content of heavy metals $(\mathrm{Cu}, \mathrm{Zn}, \mathrm{Pb}$ and $\mathrm{Cd})$ in the structure of the Kiev - Odesa road landscape engineering system as one of the main in Ukraine.

Method of implementation. Soil samples were taken at a distance of 5, 10 and $15 \mathrm{~m}$ from the Kyiv - Odesa highway to determine the moving form of heavy metals in the soil of the roadside zone. The depth of the soil sampling ranged from 0 to 10 $\mathrm{cm}$ in a fivefold repetition. Sampling of the soil was carried out in accordance with GOST (abbr. from all-Union State Standard) 17.4.3.01 and GOST 17.4.4.02. The soil samples were taken in polyethylene bags. Immediately after the selection, the soil samples were dried to the air-dry state in the room and were transferred to the laboratory of the Cherkasy branch of the state institution "Institute of Soil Protection of Ukraine". The analyses were carried out by the method of atomic absorption spectrometry according to DSTU (abbr. from State Standard of Ukraine) 4770-2-2007 (identification of zinc in the soil), DSTU 4770-9-2007 (identification of plumbum in soil), DSTU 4770-6-2007 
(identification of copper in the soil) and DSTU 4770- 3-2007 (identification of cadmium in the soil) (Львов,1966; Методичні вказівки, 2012; Новіков, 1990; Санитарные правила, 1988).

Presentation of the main research material. One of the main highways of Ukraine is the Kyiv - Odesa highway, which stretches from the north to the south almost in the meridional direction and connects the central part of Ukraine with the northern coast of Black Sea. The total length of the highway is $453.3 \mathrm{~km}$, passing through five administrative regions of Ukraine: Kyiv, Cherkasy, Kirovohrad, Mykolaiv and Odesa. According to the geological-geomorphological structure, the section of the Kyiv - Odesa highway is located within the boundaries of the Ukrainian Crystalline Shield (UCS), where pre-Cambrian sedimentary-metamorphic and igneous rocks, archean granites, gneisses and other deposits, which complicate the structure of the road landscape, appear on the surface (Маринич, 2005). The separate structures of the Crystalline Shield are the basis of formation of the Kiev - Odesa landscape-engineering system. The Bila Tserkva line of tectonic rupture of the UCS, which occupies the northeastern part of the highway, led to the formation of the valley of the Ros, Gnylyi and Girsky Tikych rivers, across which the engineering structures, bridges and overpasses of the Kyiv - Odesa highway were built. The alternation of hilly and wavy-plain terrain is connected with irregularities and the exit to the surface of crystalline rocks. According to the physical-geographical zoning, the most of the Kyiv - Odesa highway is located within the Forest-Steppe Zone; the Central and Southern parts of the highway are located in the Steppe Zone, which causes differences in soil and vegetation cover. In the northern part of the Kiev - Odesa road-landscape engineering system the soil cover is represented by alternation of chernozems opodzolic and typical with gray forest. In the central part the soil is formed by chernozems ordinary, meadow-chernozem and southern black earth. In the south there are chestnut soils in a complex with sodium soil and solod soil.

The Kyiv - Odesa highway is an international transport highway, which coincides with the direction of the European transport corridor No.9. The spatial location and coincidence of the $\mathrm{M}-05$ highway with the European transport corridor No. 9 resulted in a significant number of cars. The intensity of traffic on the Kyiv - Odesa highway is $235-508$ cars per hour, of which $72-160$ are trucks, which emit twice more harmful substances than cars (Кузнецова, 1985).
The soil samples are selected on local background areas: the first - near the town of Bila Tserkva (Kyiv region), the second one is located near the village of Nesterivka (Cherkasy region), the third in the vicinity of the village of Pikivets (Cherkasy region), the fourth area of soil selection is located near the town of Uman on the fork "Clover leaf" (Cherkasy region), where the directions of the Kiev - Odesa motorway M - 05 with the Stryi - Ternopil - Kropivnytsky - Znamyanka motorway $\mathrm{M}-12$ are crossed.

Among the heavy metals, there are about 40 chemical elements: $\mathrm{V}, \mathrm{Mn}, \mathrm{Fe}, \mathrm{Co}, \mathrm{Ni}, \mathrm{Cu}, \mathrm{Zn}$, $\mathrm{Pb}, \mathrm{Bi}, \mathrm{Cr}, \mathrm{Hg}, \mathrm{Sn}$, and others. All chemical elements are divided into three classes of danger depending on their activity and influence on soils (Сердюк, 2007). Heavy metals fall into the soil and concentrate on the depth of 0 to $20 \mathrm{~cm}$, but if there is a significant concentration of heavy metals, they penetrate to the depth of $100-150 \mathrm{~cm}$. Plumbum, zinc and cadmium are the first, copper is the second class of danger. These chemical elements and their content in the soil directly within the boundaries of the Kiev - Odesa road-landscape engineering system have been analyzed first.

The content of zinc in the soil depends on many factors including: emissions of cars, the iron-andsteel industry and non-ferrous metal industry, the properties of the parent rock, the content of various organic substances in the soil and the reaction of soil solution. In general, Ukrainian soils are poor in zinc, but in the humus layer its content is often raised. Zinc is closely connected with cadmium, the greater the concentration of zinc, the more cadmium is in the soil. The maximum permissible concentrate (MPC) of zinc in the soil is about $23 \mathrm{mg} / \mathrm{kg}$ (Fig.1). In the background areas, the content of $\mathrm{Zn}$ is within the normal range. However, on the area near the city of Uman, on the fork of the "Clover leaf", there is an abnormal area for roadside lands at a distance of $10 \mathrm{~m}$ from the road cloth. An excessive content of the mobile form of $\mathrm{Zn}$ in the soil was recorded here $-40.90 \mathrm{mg} / \mathrm{kg}$, which is not typical for this area, and exceeds the MPC almost twice (GOST 17.4.3.06-86. According to the previous studies in 2016, the zinc content at this area was $-44.50 \mathrm{mg} / \mathrm{kg}$, which is also an excess of MPC. The study area has a small area. This made it possible to distinguish it as an abnormal area of influence of heavy metals. Monitoring of zinc content near the city of Uman on the fork "Clover leaf" has shown that the amount of heavy metal in the soil gradually decreases over time. This is due to the self-cleaning of the soil, which is 
slow and in the future, this indicator can reach the norm. At present, Zn content in the soil is in excessive amounts, which is dangerous for the normal functioning of soil biota and plant formation.

The mobile form of plumbum in the soil according to DSTU $4770-9-2007$ is $6.0 \mathrm{mg} / \mathrm{kg}$. The bulk of plumbum entering the soil is due to the effect of the combustion of fuel by an automobile engine. Significant increase in the level of MPC Pb was recorded within the full-size area of Bila Tserkva. Its index is increased from the sources of pollution and reaches the maximum in the 10-meter area $9.1 \mathrm{mg} / \mathrm{kg}$, at $15 \mathrm{~m}-6.9 \mathrm{mg} / \mathrm{kg}$, which clearly exceeds the established norm of MPC (Fig. 2). On the full-size area near the village of Nesterivka the plumbum almost is not identified. On a local area of the village of Pikivets there is a tendency to reduce the amount of heavy metal content from the source of pollution. At a distance of 5 meters from the road, the plumbum value was $9.3 \mathrm{mg} / \mathrm{kg}$, which exceeded the maximum permissible concentrate. However, at distances of 10-15 meters, the content of $\mathrm{Pb}$ has almost decreased twice. On the local background area of the city of Uman - the fork of the "Clover leaf", the $\mathrm{Pb}$ content is manifested differently. At the area of 5 meters from the road, the $\mathrm{Pb}$ content is the smallest and is $4.3 \mathrm{mg} / \mathrm{kg}$, however, an increase in the MPC from 6.0 to $6.5 \mathrm{mg} / \mathrm{kg}$ was recorded at $10-15$ meters distance. Excessive amount of plumbum in the plant is able to suppress the development of plant growth and contribute to the worse flow of iron to the plant. $\mathrm{Pb}$ also has a negative affects to human health, causing various diseases associated with mutagenic reactions.

The content of cadmium in the soil by the MPC is $0.7 \mathrm{mg} / \mathrm{kg}$ and on all full-size areas of the Kiev - Odesa road landscape engineering system is within the limits of the norm $0.11-0.42 \mathrm{mg} / \mathrm{kg}$. Cadmium is interconnected with zinc, and has similar chemical properties. At the studied areas there is a tendency in decrease of the cadmium content in the soil from the source of pollution (Fig. 3). However, having compared the results of the study in 2016, cadmium content in this area has increased several times but has not exceeded the MPC. This is explained by the fact that $\mathrm{Cd}$ is concentrated in the soil as a scattered element that is easily accumulated and redistributed in soils.

The maximum permissible concentration of the mobile form of copper in the soil of the road-landscape engineering system of Kiev - Odesa is $3.0 \mathrm{mg} / \mathrm{kg}$. According to the research results, the amount of copper in soils of all full-size areas varies from $0.14-0.57 \mathrm{mg} / \mathrm{kg}$, which is a permissible norm. In most cases, the copper accumulates in loamy and sandy soils, which are background in the Kiev -Odesa road-landscape engineering system. There is a decrease in the amount of copper content from the source of pollution. In particular, there is a reduction of the content of heavy metals from the highway in the full-size area near the

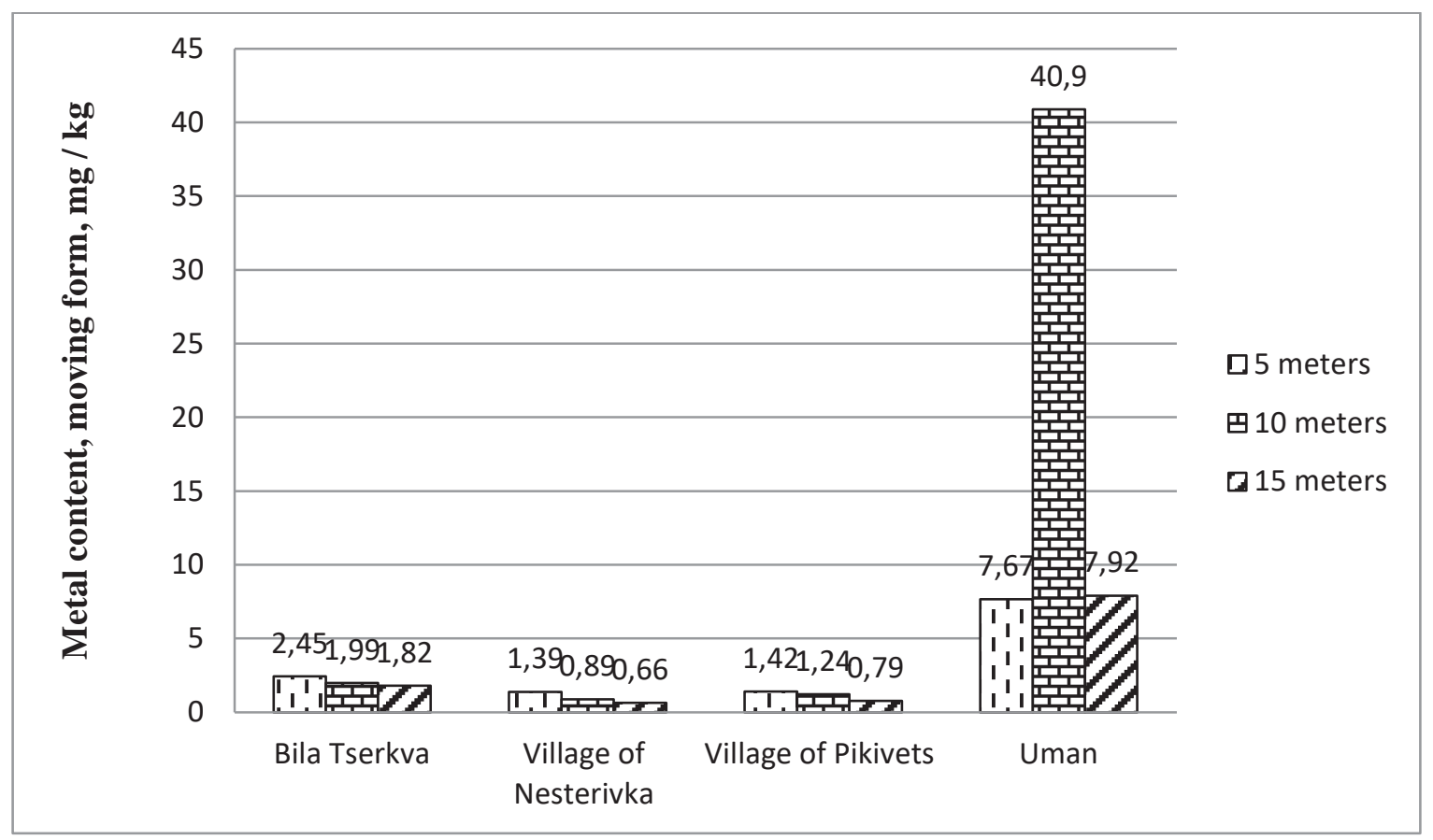

Fig. 1. The content of $\mathrm{Zn}$ in a mobile form, $\mathrm{mg} / \mathrm{kg}$ 


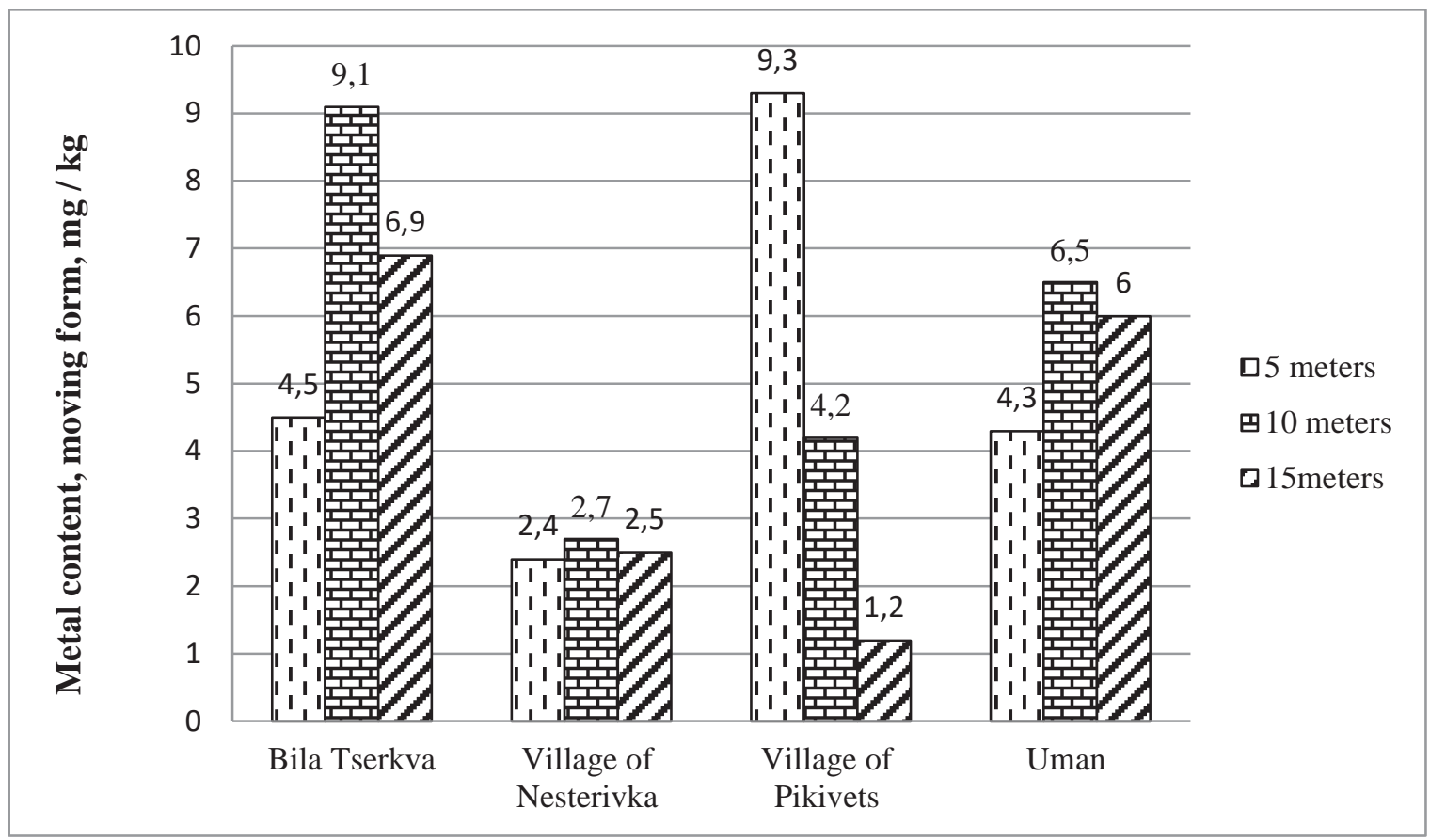

Fig. 2. Pb content in a mobile form, $\mathrm{mg} / \mathrm{kg}$

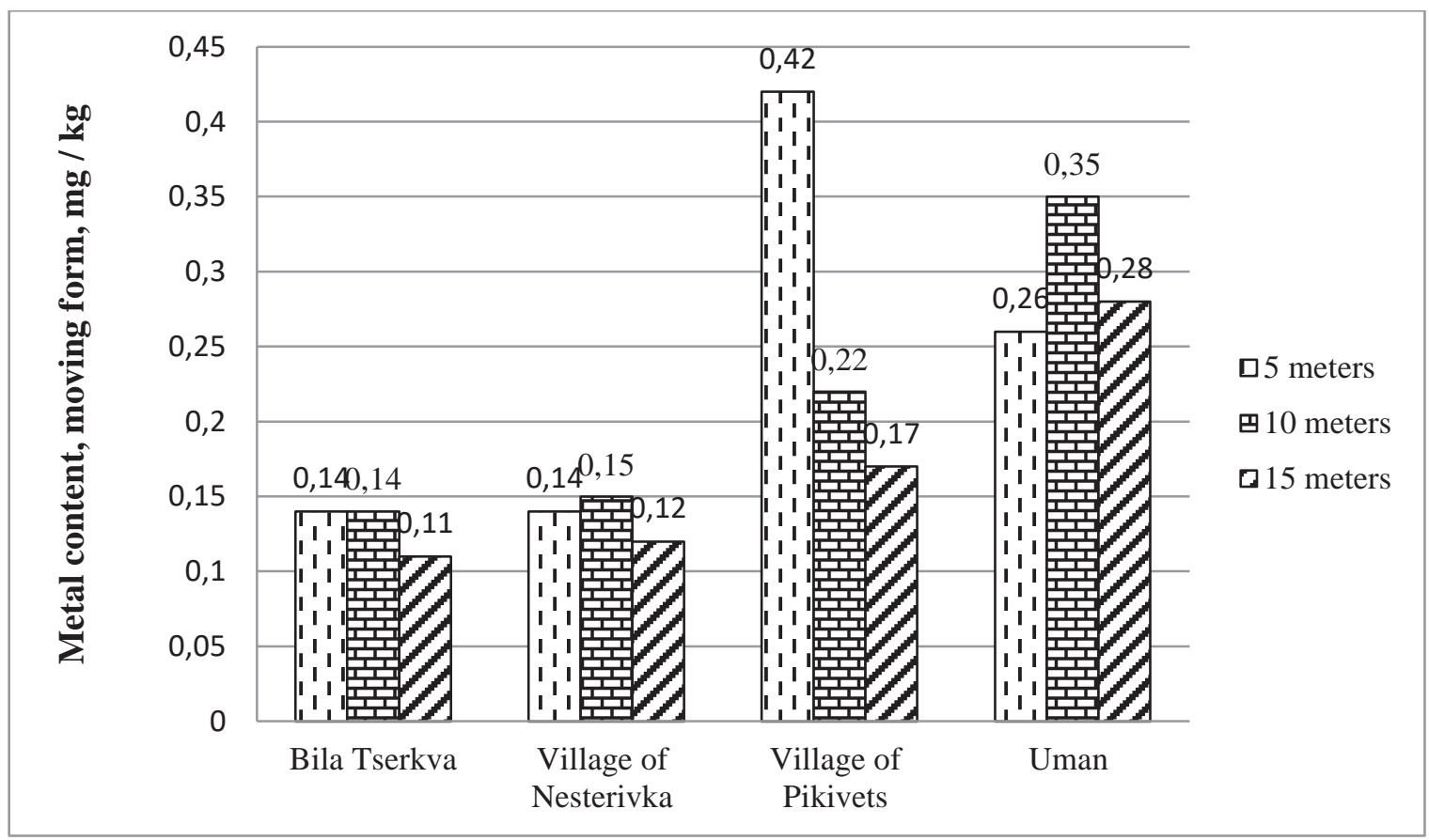

Fig. 3. Cd content in a mobile form, $\mathrm{mg} / \mathrm{kg}$

village of Pikivets (Cherkasy region) (Fig. 4). At a distance of 5 meters from the road, the amount of copper in the soil is $0.55 \mathrm{mg} / \mathrm{kg}$, however, at a distance of 10 meters the index reaches $0.33 \mathrm{mg} /$ $\mathrm{kg}$, and at the 15-meter - the copper content in the soil is $0.18 \mathrm{mg} / \mathrm{kg}$, which does not affect the functioning of plants and biota. Investigation of the copper content in the soil on the road-landscape engineering system of Kiev - Odesa in 2016 showed that the amount of this chemical element decreased in all full-size areas. This is explained by the fact that the bulk of copper is concentrated at a 5 meter area, where the dependence of the heavy metals reduction from the source of pollution is observed.

Conclusions. One of the main types of soil pollution of road landscape engineering systems by heavy metals are pollutants, which are formed as a 


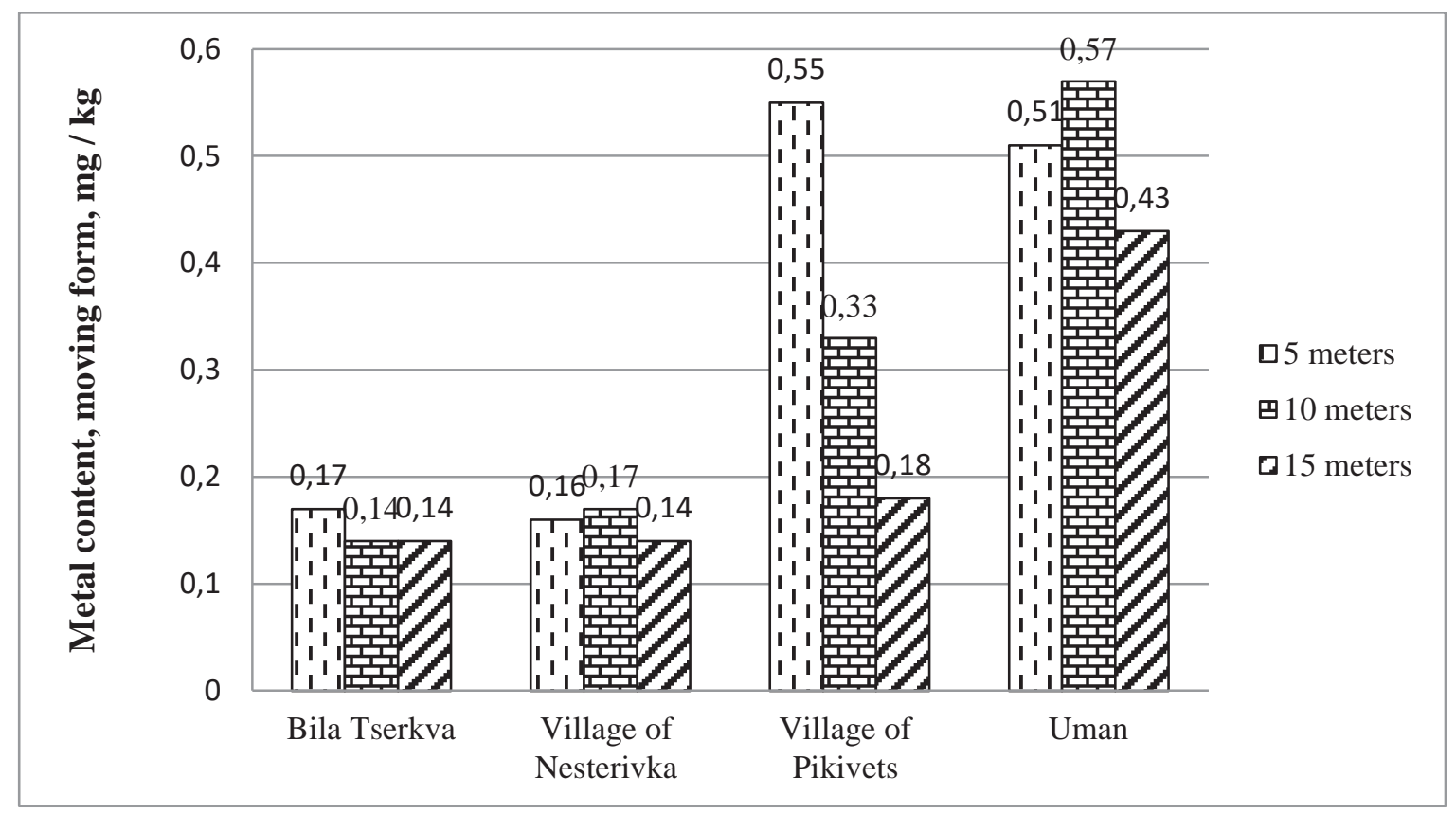

Fig. $4 \mathrm{Cu}$ content in a mobile form, $\mathrm{mg} / \mathrm{kg}$

result of combustion of fuel in automobile engines and uncontrollably emitted into the environment. In the upper part of the soil profile of the roadside area of the Kyiv -Odesa highway of $0-10 \mathrm{~cm}$, accumulation of heavy metals such as $\mathrm{Cd}, \mathrm{Cu}, \mathrm{Zn}$ and $\mathrm{Pd}$ is observed, which is primarily due to poor car operation. However, the content of heavy metals in different parts of the road is different. The abnormal areas with excessive amounts of zinc are recorded on the Kiev - Odesa highway where there is an excessive loading of vehicles. There is also an increased content of plumbum and copper. Cadmium in all full-size areas is within normal limits. In all areas there was a tendency to decrease of the heavy metals content in the soil from the source of pollution.

Consequently, within the road-landscape engineering system of Kiev - Odesa, the heavy metals in soils mostly do not exceed the MPC; however abnormal areas and zones have been recorded where the content of chemical elements is excessive and negatively influences on biota and vegetation cover. In the future, it is necessary to conduct similar geochemical studies of the soil of this road system due to the fact that after the reconstruction of the Kyiv - Odesa highway, the car load will increase by 2,5-3 times.

\section{REFERENCES:}

1. Ванчура, Р.Б. (2011). Експериментальні дослідження вмісту важких металів в охоронних зонах автомагістралей. Геодезія, картографія і аерофотознімання, 75, 110-114. [Vanchura, R.B. (2011). Experimental studies of the content of heavy metals in the protection zones of highways. Geodesy cartography and aerial photography, 75, 110-114].

2. Волошин, I.M. (2005). Особливості забруднення лісових i придорожніх насаджень автомобільних доріг загальнодержавного значення Волинської області. Науковий вісник Волинського державного університету ім. Лесі Українки. 7, 162167. [Voloshin, I.M. (2005). Peculiarities of Pollution of Forest and Roadside Plants of Highways of Volyn Oblast. Scientific Bulletin of the Volyn State University named after. Lesia Ukrainka, 7, 162-167].

3. Галаган, О.О. (2013). Моделювання розподілу важких металів у приавтомагістральних геосистемах. Фізична географія та геоморфологія, 2, 28-33. [Galagan, O.O. (2013). Modeling of the distribution of heavy metals in transverse geosystems. Physical geography and geomorphology, 2, 28-33].

4. Грабовський, О.В. (2002). Міграція та акумуляція важких металів в агроценозах, прилеглих до автомагістралей, в умовах Закарпаття (грунт-рослини-тварини) : автореф. дис. ... канд. біол. наук. Чернівецький національний університет імені Ю. Федьковича,Чернівці. [Grabovsky, O.V. (2002). Migration and accumulation of heavy metals in agrocenoses adjacent to highways, in conditions of Transcarpathia (soil-plants-animals). (Master's thesis). Chernivtsi National University named after Yuri Fedkovich, Chernivtsi].

5. Денисик, Г.І., Вальчук, О.М. (2005). Дорожні ландшафти Поділля. Вінниця : Теза. [Denisik, G. I., Valchuk, O. M. (2005). Road landscapes of Podillya. Vinnytsia : Tezis].

6. Державна служба автомобільних доріг України. (2005). Єдині правила зимового утримання 
автомобільних доріг: П Г.1-218-118. Київ. [State Road Service of Ukraine. (2005). The only rules of winter maintenance of motor roads. Kyiv].

7. Державне агентство автомобільних доріг України, (2012). Методичні вказівки щодо гранично - допустимих норм витрат протиожеледних матеріалів при зимовому утриманні автомобільних доріг: ГБН В.2.3-218-540. Київ. [State Agency of Motor Roads of Ukraine. (2012). Methodical instructions concerning the maximum - allowable rates of consumption of anti-icing materials during winter maintenance of highways: HDN B 2.3-218-540. Kyiv].

8. Довбиш, Л.Л. (2001). Забруднення важкими металами дерново-підзолистих грунтів лісоаграрних ландшафтів Полісся : автореф. дис. на здобуття наук. ступеня канд. с.-г. наук). Агроекологічний Університет, Житомир. [Dovbish, L. L. (2001). Contamination by heavy metals of turf-podzolic soils of forest-agrarian landscapes of Polissya. (Master's thesis). State Agroecological University, Zhytomyr].

9. Еськов, Е.К. (2012). Содержание свинца в растениях, произрастающих вблизи автотрасс. Земледелие теоретический и научно-практический журнал. 8. 10-11 [Eskov, E.K. (2012). Lead content in plants growing near highways. Agriculture theoretical and scientific journal, 8, 10-11].

10. Кузнецова, Б.А. (1985). Автомобильный транспорт: организация и эффективность. Москва: Транспорт. [Kuznetsov, В. А. (1985). Road transport: organization and efficiency. Moskow: Transport].

11. Львов, Б.В. (1966). Атомно-абсорбционный анализ. Москва : Наука. [Lvov, B V. (1966). Atomnoabsorption analysis. Moscow: Science].

12. Маринич, О.М., Шищенко П.Г. (2005). Фізична географія України. Київ : Знання. [Marinich, O.M. Shishchenko P.G. (2005). Physical geography of Ukraine. Kyiv: Knowledge].

13. Матвійчук, Л.Ю. (2008). Особливості забруднення важкими металами приавтомагістральних територій Волинської області : автореф. дис. на здобуття канд. геогр. наук). Національний університет імені Івана Франка, Львів. [Matviychuk, L. Yu., (2008). Osoblivosti zadrudnennya by the important metals of the otherworldly territory of Volinsky region. (Master's thesis). Ivan Franko National University of Lviv, Lviv].

14. Министерство здравоохранения СССР. (1988). Санитарные правила и нормы охраны поверхностных вод от загрязнения: СанПін № 463088. Москва. [Sanitary rules and norms of protection of surface waters from pollution. № 4630-88. (1988). Moscow].
15. Новиков, Ю.В. (1990). Методы исследования качества воды водоемов. Москва : Медицина. [Novikov, Yu.V. (1990). Methods of investigation of water quality in water bodies. Moskow: Medicine].

16. Сердюк, С.Н. (2007). Диагностика загрязнения тяжелыми металлами почвенного покрова индустриально-урбанизированных территорий. Екологія та ноосфера. 9.(1-2), 55-60. [Serdyuk, S.N. (2007). The diagnostics of heavy metal pollution of industrial-urbanized territories. Ecology and the noosphere, 19 (1-2), 55-60 ].

17. Ходан,Г.Д. (2012) Еколого-геохімічна оцінка дорожніх геосистем Чернівецької області. Науковий вісник Чернівецького університету: збірник наукових праць Чернівиі: Чернівецький університет. 614. 109111c. [Khodan, G.D. (2012). Ecological-geochemical estimation of road geosystems of Chernivtsi region. Scientific Bulletin of the Chernivtsi University: a collection of scientific works in Chernivtsi, 641, 109-111].

18. Шейкина, О.Ю. (2008). Екологічна оцінка забруднення міських грунтів важкими металами вздовж основних транспортних магістралей міста Черкаси. Екологія довкілля та безпека життєдіяльності. 1. 61-65. [Shaikina, O.Yu. (2008). Environmental assessment of soil contamination by heavy metals along the main transport highways of the city of Cherkasy. Ecology of the environment and life safety, 1, 61-65].

19. Юрченко, В.А. (2014). Исследование поверхносных сточных вод автомобильных дорог и дорожно-инфраструктурных комплексов Автошляховик України. 5,43 - 48. [Yurchenko, V.A. (2014). Investigation of surface sewage of highways and road infrastructure complexes. Roadster of Ukraine, 5, 43-48].

20. Яковенко, О.В. (2011). Особливості забруднення грунтів кадмієм та іншими важкими металами підприємствами кольорової металургії. Мінералогічний журнал. 33(2), 96-99. [Yakovenko, O.V. (2011). Features of soil pollution by cadmium and other heavy metals by non-ferrous metallurgy enterprises. Mineralogy journal, 33(2), 96-99].

21. Li, X. (2001). Heavy metal contamination of urban soils and street dusts Hong Kong. Applied Geochemistry, 6, 1361-1368. https://doi. org/10.1016/S0883-2927(01)00045-2 (дата звернення: 20.04.2019)

22. Saeedi, M. (2009). Assessment of heavy metals contamination and leaching characteristics in highway side soils. Environmental Monitoring Assessment, 151, 231-241.

Стаття надійшла до редакиії 27.05.2019 